\title{
Cityscape, poverty and crime: A quantitative assessment using VHR imagery
}

\author{
Autor: Jorge Eduardo Patiño Quinchía \\ Directores: Luis Ángel Ruiz Fernández, Josep Eliseu Pardo Pascual y Juan Carlos Duque Cardona
}

Lugar: Universitat Politècnica de València

Fecha: 21/12/2015

Calificación: Sobresaliente Cum Laude

Disponible: http://hdl.handle.net/10257/59453

This work starts by reviewing the potential applications of satellite remote sensing to regional science research in urban settings. Regional science is the study of social problems that have a spatial dimension (Isard, 1975; Isserman, 2004). The availability of satellite remote sensing data has increased significantly in the last two decades, and these data constitute a useful data source for mapping the composition of urban settings and analyzing changes over time (Weng \& Quattrochi, 2006). The increasing spatial resolution of commercial satellite imagery has influenced the emergence of new research and applications of regional science in urban settlements because it is now possible to identify individual objects of the urban fabric (Sliuzas et al., 2010).

Although the variables of interest for regional scientists are not directly measured from the air, remote sensing can measure the context of social phenomena and their effects on the land surface (Rindfuss \& Stern, 1998). The relationships between urban land cover and other environmental factors and the variables that describe socioeconomic conditions have been explored since the late 1950s with the use of aerial photography (Green, 1956, 1957). Research in the last three decades has explored the use of satellite remote sensing to characterize these relationships at a lower cost. In the urban environment, these relationships are based on the concept that the physical appearance of an urban settlement is a reflection of the society that created it and on the assumption that people living in urban areas with similar physical housing conditions will have similar social and demographic characteristics (Jain, 2008; Taubenböck et al., 2009).

The most common applications found in the literature are the detection of urban deprivation hot spots (Barros, 2008; Hofmann et al., 2008; Kohli et al., 2012), quality of life index assessment (Forster, 1983; Lo, 1997; Jensen et al., 2004), urban growth analysis (Rashed et al., 2005; Doll, 2008; Doxani et al., 2012), house value estimation (Jensen et al., 2004; Yu \& Wu, 2006; Taubenböck et al., 2009), urban population estimation (Jensen \& Cowen, 1999; Pozzi \& Small, 2005; Liu et al., 2006), urban social vulnerability assessment (Rashed et al., 2007; Taubenböck et al., 2008; Ebert et al., 2009), and the variability of intra-urban crime rates (Kuo \& Sullivan, 2001; Browning et al., 2010; Donovan \& Prestemon, 2012).

The satellite remote sensing imagery used in these applications has medium, high or very high spatial 
resolution, such as images from Landsat MSS, Landsat TM and ETM+, SPOT, ASTER, IRS, Ikonos and QuickBird. Consistent relationships between socio-economic variables derived from censuses and field surveys and proxy variables of vegetation coverage measured from satellite remote sensing data have been found in several cities in the US (Mennis, 2006; Jenerette et al., 2007; Li \& Weng, 2007). Different approaches and techniques have been applied successfully around the world, but local research is always needed to account for the unique elements of each place. Spectral mixture analysis, object-oriented classifications and image texture measures are some of the techniques of image processing that have been implemented with good results (Patino \& Duque, 2013). Many regional scientists remain skeptical that satellite remote sensing will produce useful information for their work. More local research is needed to demonstrate the real potential and utility of satellite remote sensing for regional science in urban environments.

The second part of this work focuses on data manipulation and extraction of urban fabric descriptors from a very high spatial resolution(VHR) image, and the integration with socioeconomic data at object level. We extract information on land cover composition using per-pixel classification and on urban texture and structure using an automated tool for texture and structure feature extraction at object level (Ruiz et al., 2011). We use data from Medellin (Colombia), which is the second larger city in the country, and it has been one of the most violent cities in the world in past decades and is still one of the most socioeconomically divergent (Duque et al., 2013a). This city is a useful location for conducting intra-urban variability studies because it has experienced high population growth rates since the 1950s, and the unplanned urban growth in some parts of the city resulted in a high degree of spatial heterogeneity in both the socioeconomic and physical characteristics of its neighborhoods.

The third part of this work contributes empirical evidence about the usefulness of remote sensing imagery to quantify the degree of poverty at the intra-urban scale. This concept is based on two premises: first, that the physical appearance of an urban settlement is a reflection of the society; and second, that the people who reside in urban areas with similar physical housing conditions have similar social and demographic characteristics (Jain, 2008; Taubenböck et al., 2009). We evaluate the potential of the image-derived urban fabric descriptors to explain a measure of poverty known

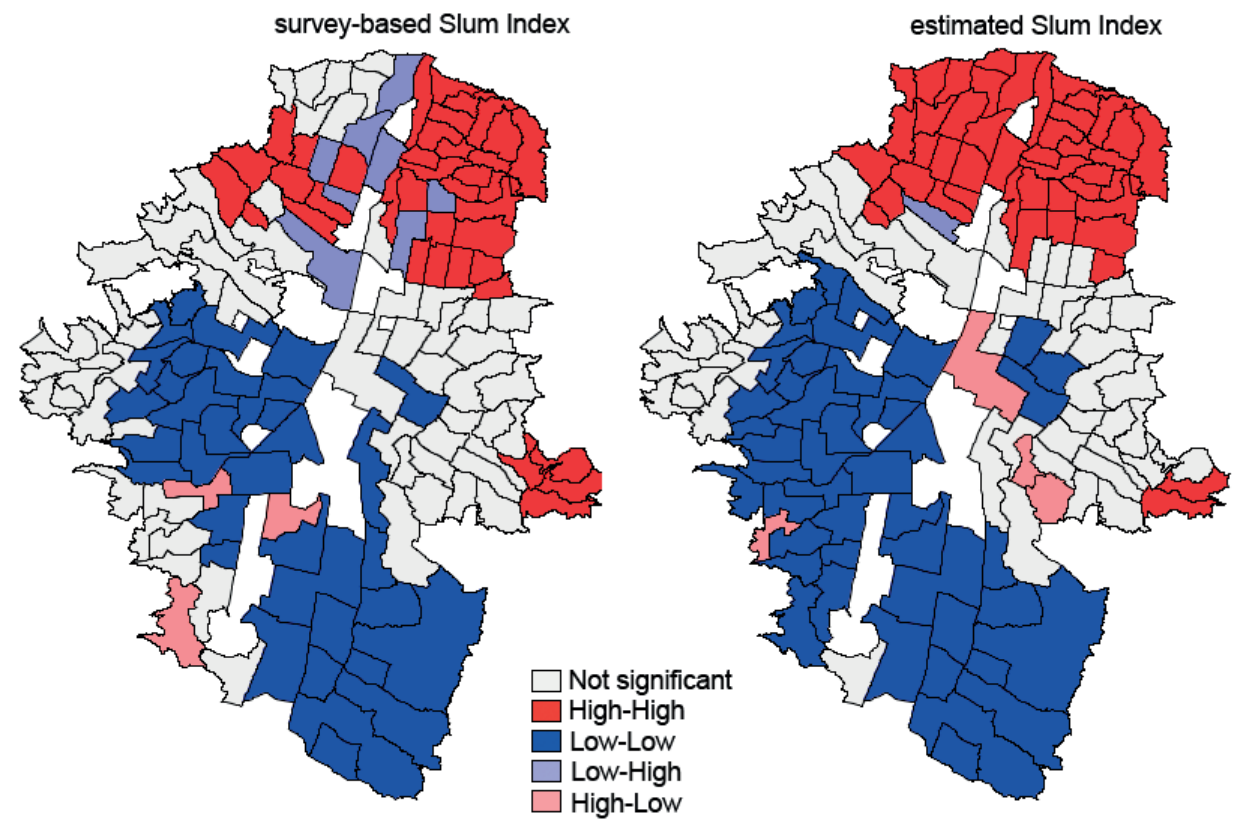

Figure 1. LISA maps of survey based Slum index (left) vs. estimated Slum index from image-derived variables. 
as the Slum Index (Weeks et al., 2007). We found that these variables can explain up to $59 \%$ of the variability in the Slum Index in Medellin, Colombia. Similar approaches could be used to lower the cost of socioeconomic surveys by developing an econometric model from a sample and applying that model to the rest of the city and to perform intercensal or intersurvey estimates of intra-urban
Slum Index maps (Duque et al., 2015, 2013b). Figure 1 shows the spatial clusters of high and low values of the Slum index across the city computed from survey data vs. computed from image-derived data. Spatial clusters of high values, showed in red, indicate areas of concentrated poverty, while spatial clusters of low values, showed in blue, indicate areas of concentrated affluence.
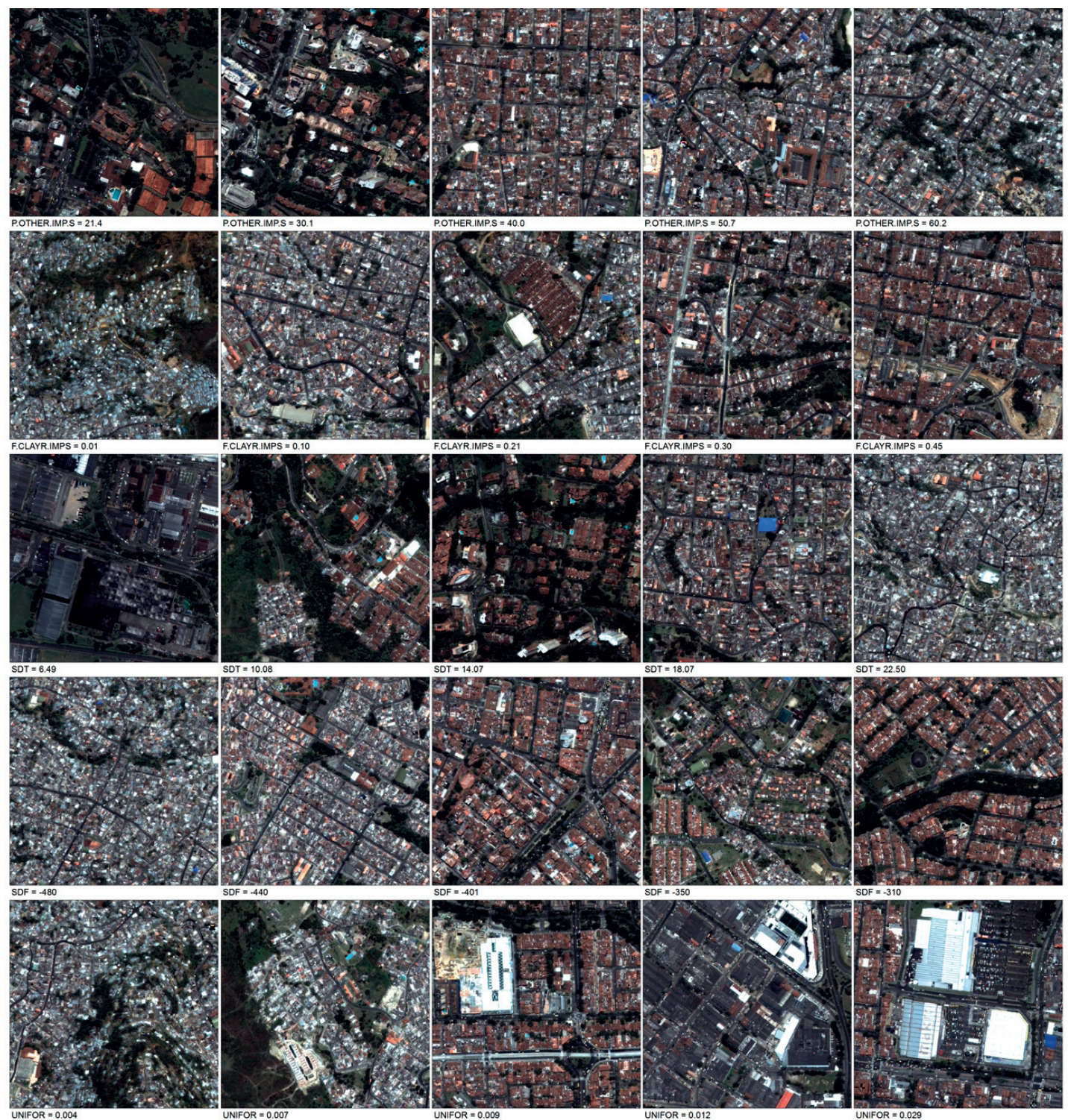

Figure 2. Square image tiles $(500 \times 500$ meters) organized from left to right according to increasing values of the best performing remote sensing variables in homicide model specification. From top to bottom: percentage of impervious surfaces other than clay roofs (P.OTHER.IMP.S), fraction of clay roofs within impervious surfaces (F.CLAYR.IMPS), structure variables SDT and SDF, and texture variable uniformity (UNIFOR). 
The last part of this work analyzes the relation between the urban layout and crime. The link between place and crime is at the base of social ecology theories of crime that focus in the relationship of the characteristics of geographical areas and crime rates (Anselin et al., 2000; Cullen \& Agnew, 2011). The broken windows theory states that visible cues of physical and social disorder in a neighborhood can lead to an increase in more serious crime (Shaw \& McKay, 1942; Wilson \& Kelling, 1982). The crime prevention through environmental design (CPTED) planning approach seeks to deter criminal behavior by creating defensible spaces (Cozens, 2008). Based on the premise that a settlement's appearance is a reflection of the society, we ask whether a neighborhood's design has a quantifiable imprint when seen from space using urban fabric descriptors computed from VHR imagery.

We tested which land cover, structure and texture descriptors were significantly related to intraurban homicide rates in Medellin, Colombia, while controlling for socioeconomic confounders. The percentage of impervious surfaces other than clay roofs, the fraction of clay roofs to impervious surfaces, two structure descriptors related to the homogeneity of the urban layout, and the uniformity texture descriptor were all statistically significant. Figure 2 shows square image tiles of urban areas that have different values of the best performing remote sensing variables in model specification. Areas with higher homicide rates tended to have higher local variation and less general homogeneity; that is, the urban layouts were more crowded and cluttered, with small dwellings with different roofing materials located in close proximity to one another, and these regions often lacked other homogeneous surfaces such as open green spaces, wide roads, or large facilities. These results seem to be in agreement with the broken windows theory and CPTED in the sense that more heterogeneous and disordered urban layouts are associated with higher homicide rates (Patino et al., 2014).

\section{Acknowledgements}

This research was made possible by funding of Medellin City Hall Enlaza-Mundos program, 20102 Call, and EAFIT University, Colombia, research projects 342-000033 (2012), 435-000060 (2013), and 513-000084 (2014). The author also thanks Professor John Weeks, director of the International Population Center at San Diego State University and professors Hermilson Velázquez, Andrés Ramírez Hassan and Gustavo Canavire at EAFIT University for their insightful observations and suggestions during the different stages of this work.

\section{References}

Anselin, L., Cohen, J., Cook, D., Gorr, W., Tita, G. 2000. Spatial analyses of crime. Criminal Justice, 4, 213-262.

Barros, M. 2008. Slums detection through lacunaritybased texture analysis of remote sensing images. Expert group meeting on slum mapping. ITC, The Netherlands. Enschede: ITC, UN-HABITAT, CIESIN.

Browning, C. R., Byron, R. A., Calder, C. A., Krivo, L. J., Kwan, M.-P., Lee, J.-Y., Peterson, R. D. 2010. Commercial density, residential concentration, and crime: Land use patterns and violence in neighborhood context. Journal of Research in Crime and Delinquency, 47(3), 329-357. http://dx.doi. org/10.1177/0022427810365906

Cozens, P. M. 2008. New Urbanism, crime and the suburbs: A review of the evidence. Urban Policy and Research, 26(4), 429-444. http://dx.doi. org/10.1080/08111140802084759

Cullen, F. T., Agnew, R. 2011. The Chicago School: The city, social disorganization, and crime. En F. T. Cullen \& R. Agnew (Eds.), Criminological theory: past to present. Essential readings (4th ed., pp. 89117). New York, Oxford: Oxford University Press.

Doll, C. N. H. 2008. CIESIN thematic guide to nighttime light remote sensing and its applications. Center for International Earth Science Information Network (CIESIN). Palisades, NY: Center for International Earth Science Information Network (CIESIN), Columbia University.

Donovan, G. H., Prestemon, J. P., 2012. The effect of trees on crime in Portland, Oregon. Environment and Behavior, 44(1), 3-30. http://dx.doi. org/10.1177/0013916510383238

Doxani, G., Karantzalos, K., Strati, M. T. 2012. Monitoring urban changes based on scalespace filtering and object-oriented classification. International Journal of Applied Earth Observation and Geoinformation, 15, 38-48. http://dx.doi. org/10.1016/j.jag.2011.07.002

Duque, J. C., Patino, J. E., Ruiz, L. A., Pardo-Pascual, J. E. 2013a. Quantifying slumness with remote sensing data. CIEF working paper, EAFIT University, No. $13-23$. 
Duque, J. C., Patino, J. E., Ruiz, L. A., Pardo-Pascual, J. E. 2015. Measuring intra-urban poverty using land cover and texture metrics derived from remote sensing data. Landscape and Urban Planning, 135, 11-21. http://dx.doi.org/10.1016/j. landurbplan.2014.11.009

Duque, J. C., Royuela, V., Noreña, M. 2013b. A stepwise procedure to determine a suitable scale for the spatial delineation of urban slums. En E. Fernandez \& F. Rubiera Morollón (Eds.), Defining the spatial scale in modern regional analysis. Advances in Spatial Science (pp. 237-254). Berlin Heidelberg: SpringerVerlag.

Ebert, A., Kerle, N., Stein, A. 2009. Urban social vulnerability assessment with physical proxies and spatial metrics derived from air- and spaceborne imagery and GIS data. Natural Hazards, 48(2), 275294. http://dx.doi.org/10.1007/s11069-008-9264-0

Forster, B. 1983. Some urban measurements from Landsat data. Photogrammetric Engineering and Remote Sensing, 49(12), 1693-1707.

Green, N. E. 1956. Scale analysis of urban structures: A study of Birmingham, Alabama. American Sociological Review, 21(1), 8-13. http://dx.doi. org/10.2307/2089333

Green, N. E. 1957. Aerial photographic interpretation and the social structure of the city. Photogrammetric Engineering, 23, 89-99.

Hofmann, P., Strobl, J., Blaschke, T., Kux, H. J. H. 2008. Detecting informal settlements from QuickBird data in Rio de Janeiro using an object-based approach. En T. Blaschke, S. Lang, \& G. J. Hay (Eds.), Object-based image analysis - Spatial concepts for knowledge-driven remote sensing applications. (pp. 531-553). New York: Springer. http://dx.doi. org/10.1007/978-3-540-77058-9_29

Isard, W. 1975. An introduction to regional science. Englewood Cliffs, N.J.: Prentice Hall.

Isserman, A. M. 2004. Intellectual leaders of regional science: A half-century citation study. Papers in Regional Science, 83(1), 91-126. http://dx.doi. org/10.1007/s10110-003-0178-7

Jain, S. 2008. Remote sensing application for property tax evaluation. International Journal of Applied Earth Observation and Geoinformation, 10(1), 109121. http://dx.doi.org/10.1016/j.jag.2007.10.008

Jenerette, G. D., Harlan, S. L., Brazel, A., Jones, N., Larsen, L., Stefanov, W. L. 2007. Regional relationships between surface temperature, vegetation, and human settlement in a rapidly urbanizing ecosystem. Landscape Ecology, 22(3), 353-365. http://dx.doi.org/10.1007/s10980-0069032-Z
Jensen, J. R., Cowen, D. C. 1999. Remote sensing of urban/suburban infrastructure and socio-economic attributes. Photogrammetric Engineering and Remote Sensing, 65(5), 611-622.

Jensen, R., Gatrell, J., Boulton, J., Harper, B. 2004. Using remote sensing and geographic information systems to study urban quality of life and urban forest amenities. Ecology and Society, 9(5), 5-15.

Kohli, D., Sliuzas, R., Kerle, N., Stein, A. 2012. An ontology of slums for image-based classification. Computers, Environment and Urban Systems, 36(2), 154-163. http://dx.doi.org/10.1016/j. compenvurbsys.2011.11.001

Kuo, F. E., Sullivan, W. C. 2001. Environment and crime in the inner city. Does vegetation reduce crime? Environment and Behavior, 33(3), 343-367. http://dx.doi.org/10.1177/00139160121973025

Li, G., Weng, Q. 2007. Measuring the quality of life in city of Indianapolis by integration of remote sensing and census data. International Journal of Remote Sensing, 28(2), 249-267. http://dx.doi. org/10.1080/01431160600735624

Liu, X., Clarke, K. C., Herold, M. 2006. Population density and image texture: A comparison study. Photogrammetric Engineering and Remote Sensing, 72(2), 187-196. http://dx.doi.org/10.14358/ PERS.72.2.187

Lo, C. P. 1997. Application of LandSat TM data for quality of life assessment in an urban environment. Computers, Environment and Urban Systems, 21(3-4), 259-276. http://dx.doi.org/10.1016/S01989715(97)01002-8

Mennis, J. 2006. Socioeconomic-vegetation relationships in urban, residential land: the case of Denver, Colorado. Photogrammetric Engineering and Remote Sensing, 72(8), 911-921. http://dx.doi. org/10.14358/PERS.72.8.911

Patino, J. E., Duque, J. C. 2013. A review of regional science applications of satellite remote sensing in urban settings. Computers, Environment and Urban Systems, 37, 1-17. http://dx.doi.org/10.1016/j. compenvurbsys.2012.06.003

Patino, J. E., Duque, J. C., Pardo-Pascual, J. E., Ruiz, L. A. 2014. Using remote sensing to assess the relationship between crime and the urban layout. Applied Geography, 55, 48-60. http://dx.doi. org/10.1016/j.apgeog.2014.08.016

Pozzi, F., Small, C. 2005. Analysis of urban land cover and population density in the United States. Photogrammetric Engineering and Remote Sensing, 71(6), 719-726. http://dx.doi. org/10.14358/PERS.71.6.719 
Rashed, T., Weeks, J., Couclelis, H., Herold, M. 2007. An integrative GIS and remote sensing model for place-based urban vulnerability analysis. En V. Mesev (Ed.), Integration of GIS and remote sensing (pp. 199-233). John Wiley \& Sons, Ltd.

Rashed, T., Weeks, J. R., Stow, D., Fugate, D. 2005. Measuring temporal compositions of urban morphology through spectral mixture analysis: toward a soft approach to change analysis in crowded cities. International Journal of Remote Sensing, 26(4), 699-718. http://dx.doi.org/10.1080/ 01431160512331316874

Rindfuss, R. R., Stern, P. C. 1998. Linking remote sensing and social science: The need and the challenges. En D. Liverman, E. F. Moran, R. R. Rindfuss, P. C. Stern (Eds.), People and pixels: Linking remote sensing and social science (pp. 1-27). Washington, D.C.: National Academy Press.

Ruiz, L. A., Recio, J. A., Fernández-Sarría, A., Hermosilla, T. 2011. A feature extraction software tool for agricultural object-based image analysis. Computers and Electronics in Agriculture, 76(2), 284-296. http://dx.doi.org/10.1016/j. compag.2011.02.007

Shaw, C. R., McKay, H. D. 1942. Juvenile Delinquency and Urban Areas. Chicago: University of Chicago Press.

Sliuzas, R., Kuffer, M., Masser, I. 2010. The spatial and temporal nature of urban objects. En T. Rashed, C. Jürgens (Eds.), Remote sensing of urban and suburban areas (pp. 67-84). Dordrecht: Springer Netherlands. http://dx.doi.org/10.1007/978-14020-4385-7_5

Taubenböck, H., Post, J., Roth, A., Zosseder, K., Strunz, G., Dech, S. 2008. A conceptual vulnerability and risk framework as outline to identify capabilities of remote sensing. Natural Hazards and Earth System Science, 8(3), 409-420. http://dx.doi.org/10.5194/ nhess-8-409-2008

Taubenböck, H., Wurm, M., Setiadi, N., Gebert, N., Roth, A., Strunz, G., Birkmann, J., Dech, S. 2009. Integrating remote sensing and social science - The correlation of urban morphology with socioeconomic parameters. IEEE 2009 Urban Remote Sensing Joint Event. London.

Weeks, J. R., Hill, A. G., Stow, D., Getis, A., Fugate, D. 2007. Can we spot a neighborhood from the air? Defining neighborhood structure in Accra, Ghana. GeoJournal, 69(1-2), 9-22. http://dx.doi. org/10.1007/s10708-007-9098-4

Weng, Q., Quattrochi, D. A., 2006. Urban remote sensing. Boca Raton: CRC Press - Taylor \& Francis Group. http://dx.doi.org/10.1201/b15917
Wilson, J. Q., Kelling, G. L. 1982. Broken windows: The police and neighborhood safety. Atlantic Monthly, 249(3), 29-38.

Yu, D., Wu, C. 2006. Incorporating remote sensing information in modeling house values : A regression tree approach. Photogrammetric Engineering and Remote Sensing, 72(2), 129-138. http://dx.doi. org/10.14358/PERS.72.2.129 